\title{
トンネルの凍害・東上防止工設計のための 気象条件の評価
}

\section{1. まえがき}

鉄道トンネル約 3800 本のうち，約 30\%に相当す る 1100 本のトンネルには冬期につららや側水が発 生し，鉄道車両の走行安全性を阻害することが多い。 さらに，地山の東結が覆工背面にまで及ぶと地山の 凍上によって，トンネルの変状を来すものもある。

このようなトンネルの東害・倲上を防止する工法 の一つとして開発された，トンネルの断熱つらら防

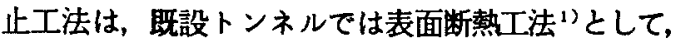
新設トンネルでは断熱二重巻復工工法"2)として，多 くの施工実績を積み重ね，メンテナンスフリートン ネルとして保守サイドからだけでなく建設サイドか らも着目されている。

断熱つらら防止工法の設計の基本となる断熱材の 厚さや有効幅を決定するにはトンネルの気象条件が 必要となるが，当論文はこの気象条件である年平均 気温，その年振幅之日振幅を Gumbel の第一種極値 分布解析を用いて推定する手法について述べたもの である。これによって，トンネルの防災強度が定量 的に確定できることになり，断熱つらら防止工の設 計が合理的にできることになった。

\section{2. 断焦つらら防止工の概要}

\section{1 断熱つらら防止工の概念}

断熱つらら防止工は，覆工表面あるいは復工中間 に断熱材を設置するものであり，断熱材以深の覆工 や地山の熱を冬期になるべくトンネル内空側に放出
岡田勝也*

しないことによって，断熱材背面の温度を水点以上 に保持しようとするものである。

既設トンネルの改良では，鉄道車両の間合いの関 係から夜間作業であ工事が可能なように，図一1に 示すように，既設覆工の表面に防水工を施工した後， 断熱材を吹き付けたり，断熱板を設置したりするも のである。この場合には，冬期につららが発生する 筒所があらかじめ判っているので，ある有効幅につ いてのみ表面断熱工法を施工すれば良い。

新設トンネルでは, NATM（New Austrian Tunnelling Method : トンネルの掘削工法の一つで, ロックボルトと吹付コンクリートを組み合わせた工 法）における一次提工と二次夏工の間に，防水シー トと断熱工を施工するものであり，断熱二重巻覆工

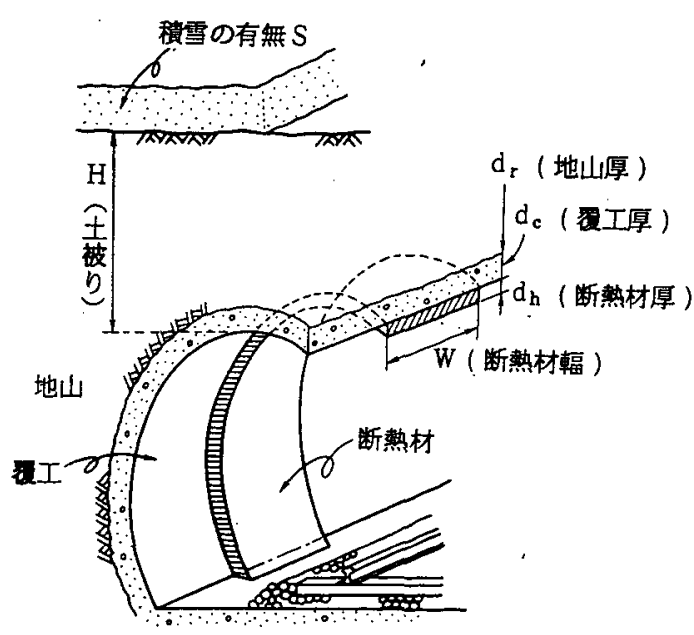

図一１ 既設トンネルの断熱つらら防止工の概念図 
と呼ばれるすのである。

\section{2 トンネル内気温の周期的変動に対する}

\section{温度举動}

(1) 断熱つらら防止工の温度挙動の概念 ${ }^{1.2)}$

断熱つらら防止工を施工するトンネルにおいて， 土被り $\mathrm{H}$ が十分厚く，かつ断熱材の幅 W が大きい 場合には，トンネル地山の温度挙動は, トンネル内 気温，断熱材，覆工と地山によって表される三層の 異物質加ら構成される一次元非定常熱伝達／熱伝導 モデルで十分解析でき，その結果については既に報 告されている1.2)。

いま，既設トンネルを対象とした表面断熱工法に おいて, 断熱材厚, 覆工厚と地山厚を図一 2 に示す ようにそれぞれ $d_{h}, d_{c}$ とdrで表わした時，トンネ ル内気温の年平均気温 $\mathrm{t}_{\mathrm{m}}$ ， その年周期变動（年掁 幅 $A_{r}$ ）と日周期变動（日振幅 $A_{D}$ ）に対して,つ らら防止工としては断熱材背面温度の最小值が $\boldsymbol{\Theta}_{\text {a min }}>0{ }^{\circ} \mathrm{C}$ を満足する条件として,

$$
t_{m} / A_{Y}>_{k_{Y, B}}+\eta k_{D, B}
$$

を与えている。ここに， $A_{Y, B}$ を年周期挙動に対す る断熱材背面の温度振幅, $A_{D, B}$ を日周期挙動に対 するそれとすれば，無次元振幅 $k_{Y, B} k_{D, B}$ は，

$$
\begin{aligned}
& k_{Y, B}=A_{Y, B} / A_{Y} \\
& k_{D, B}=A_{D, B} / A_{D}
\end{aligned}
$$

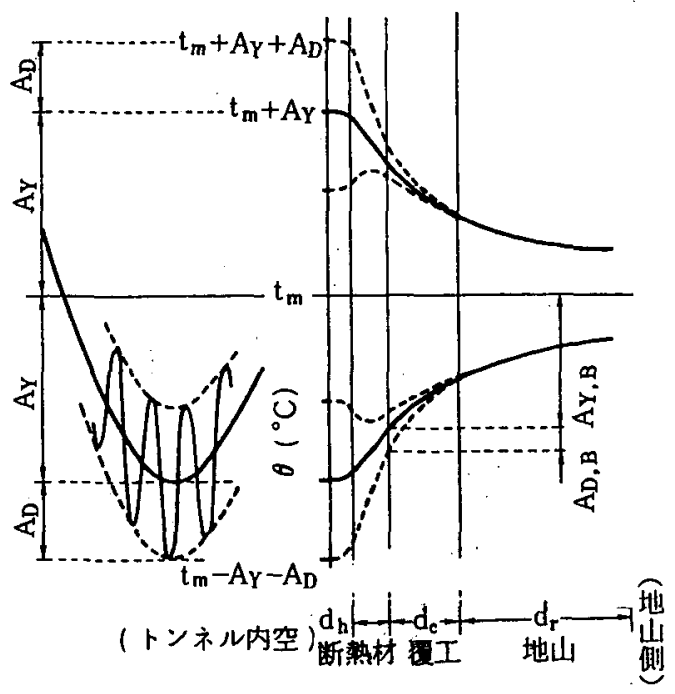

図一２トンネル横断面の温度挙動の概念図
日振幅と年振幅の比 $\eta$ は,

$$
\eta=A_{D} / A_{\gamma}
$$

である。

ここで, $k_{Y, B}$ と $k_{D, B}$ は非定常熱伝達/熱伝導解析 により得られるるのであるから式(1)を満足するよ うに断熱材の厚さ $d_{h}$ を決定すればよいことになる。 なお，断熱材の厚さ $d_{h}$ 之無次元振幅 $k_{Y, B}, k_{D, B}$ の 関係は，式(4)に示される断熱材の無次元熱伝導率 $\beta_{\mathrm{h}}$ と地山の無次元熱伝導率 $\beta_{\mathrm{r}}$ をパラメーターに 既に求められている

すなわち， $\beta_{\mathrm{b}}$ は覆エコンクリートの熱伝導率 $\lambda_{\mathrm{c}}$ に対する断熱材の熱伝導率 $\lambda_{\mathrm{h}}$ の比，また $\beta r$ は $\lambda$ 。に対する地山の熱伝導率 $\lambda$ ，の比で表される。

$$
\begin{aligned}
& \beta_{\mathrm{h}}=\lambda_{\mathrm{b}} / \lambda_{\mathrm{c}} \\
& \beta_{\mathrm{r}}=\lambda_{\mathrm{r}} / \lambda_{\mathrm{c}}
\end{aligned}
$$

したがって,トンネルの存在する位置の気象条件, すなわち年平均気温 $t_{m}$, 年振幅 $A_{r}$ と日振幅・年振 幅比 $\eta か ゙$ 決定できれば，断熱つつら防止工における 断熱材の厚さなどが算定できることになる。

(2) トンネル内気温の娍衰に関する概念 ${ }^{3,4}$ )

鉄道トンネルのつらら発生領域に関する解析によ れば, トンネル坑口からの距離とトンネル坑口の気 温振幅とトンネル内気温の振幅の比 $A_{z} / A_{0}$ の関係 は, 図一 3 のトンネル内流体の温度减衰モデルに対 して，式(5)のように提案されている3)。

$A_{o}$ をトンネル坑口における気温の振幅, $A_{z}$ を坑 ロから $\mathrm{z}$ の距離にあるトンネル内気温の振幅とした 時,

$$
A_{z} / A_{o}=\exp (-\kappa z \cdot \cos \xi)
$$

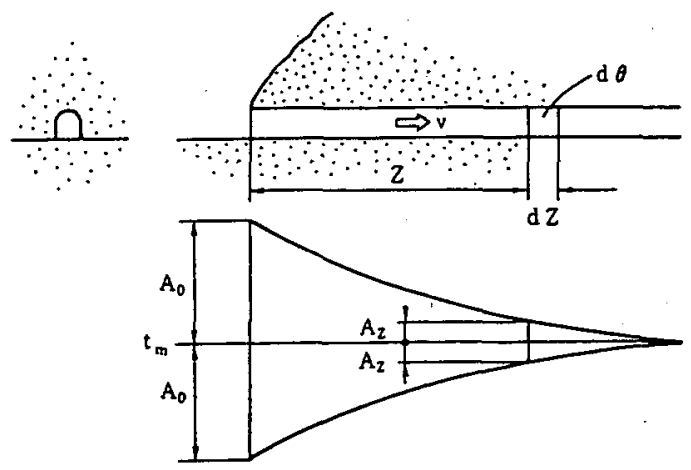

図-3 トンネル内気温の振幅減衰の概念 
ここに,

$$
\begin{aligned}
& h=a / \lambda \\
& \phi=\sqrt{\omega / 2 a} \\
& \eta=1 / \sqrt{1+2(\phi / h)+2(\phi / h)^{2}} \\
& \varepsilon=\tan ^{-1}[(\phi / h) /\{1+(\phi / h)\}] \\
& \kappa=2 \sqrt{2} \phi \eta \lambda / \text { rroc, } v \\
& \xi=\pi / 4-\varepsilon
\end{aligned}
$$

で与えた。 $a$ はトンネルの覆工表面における熱伝達 率, roはトンネルの換算半径, $r$ はトンネル内空 気の比重量， $c_{p}$ はトンネル内空気の定圧比熱， $v$ は トンネル内風速である。なお， $\omega$ は，トンネル外気 温が振幅 $A_{\text {。 }}$

$$
\theta=t_{m}+A_{o} \sin \omega t
$$

で変動する場合の角速度であり，また $a$ は温度伝導 度で $\mathrm{c}_{\boldsymbol{\rho}}$ を熱容量とすれば,

$$
a=\lambda / c_{\rho}
$$

で与えられる。

したがって，トンネル坑口より奥に入った所に断 熱つらら防止工を施工する場合には，トンネル外気 温の年振幅 $A_{Y}$ と日掁幅 $A_{D}$ を式(5)にしたがって 減衰した值を用いればより合理的な設計ができるこ とになる。なお,、トンネル全長にわたり断熱つらら 防止工を施工する場合には若干の補正が必要であ る)。

\section{3.トンネル外気温の第一種極値分布の適用}

\section{1 基礎データの算出}

断熱つらら防止工を設計する場合の基礎データと して, トンネル外気温の年平均気温 $t_{m}$, その年振 幅 $A_{Y}$ ，日振幅 $A_{D}$ が必要になることは，2.2(1)で述 へた。これらの気象条件の変数は確率分布として求 めるべきと考えられる。

確率分布モデルとしては，正規分布の特性を利用 する方法, 直接非対称分布関数を当てはめる方法に 大別される。前者には対数正規, $\mathrm{n}$ 乗根正規, 経験 的分布関数の直接正規化するなどの方法がある。後 者には，指数型分布，ガンマ分布，極值分布などが ある。積率解と呼ばれる Fisher, Slade, 岩井, 石 原・高瀬の方法は対数正規分布に属するものであり,
Gumbel, Jenkinson 等の方法は極值分布に相当す るものである。

JR では確率雨量の計算に際し，上述の対数正規 分布の岩井による方法が古くは用いられてきたが， 最近では確率雨量や確率雪量の計算に Gumbel の方 法を用いている。ここでは，JR の保守現場で用い られることを考慮し，Gumbel の第一種極值分布を トンネル外気温の気象条件の推定に適用することを 試みる。

Gumbel の第一種極値分布は, 非超過確率 $\mathrm{p}$ に対 応する極值を $y_{p}$ とすると

$$
y_{p}=u \pm a^{-1} \ln \left(-\ln \left(1-m^{-1}\right)\right)
$$

で表されるらっ。

ここに $\mathrm{m}$ は再睍期間であり,また $u$ と $\boldsymbol{a}$ は, 統 計データの平均値と標準偏差をそれぞれ $\mu_{\mathrm{Y}}$ と $\sigma_{\mathrm{Y}}$ とすれば,

$$
\begin{aligned}
& u=\mu_{Y} \pm\left(y_{n} / \sigma_{n}\right) \sigma_{Y} \\
& a=\sigma_{n} / \sigma_{Y}
\end{aligned}
$$

である。なお, $y_{n}$ と $\sigma_{n}$ は統計個数 $\mathrm{n}$ の期待平均值 と期待標準偏差であるが, $n=\infty$ の時には, $y_{\mathrm{n}} / \sigma_{\mathrm{n}}=0.4550, \sigma_{\mathrm{n}}=1.283$ となる。なお，式(8) と(9)の士は最小㥛値，最大極値を指す。

さて極值分布を実行するにあたって， $n$ 回の観测 て観測された変量の大きさ $X_{n}(\mathrm{n}=1,2, \cdots \mathrm{n})$ を求める必要があるが, $X_{n}$ に相当する気象条件 $t_{m}$ $A \mathrm{y}, A_{D}$ は，トンネル近傍の気象官署あるいは JR の保守機関の観测データが基本データとなる。

JRの保守現場で得られた日最高気温と日最低気 温の一例は図ー4のようである。図は高山本線巣の 内トンネルの一年間の観湘データを描いたすのであ るが，これを基礎データとして当該年度の変量 $\mathrm{X}_{\mathrm{i}}$ を算出する。

実測データである年度の $m$ 月 $n$ 日の日最高気温 を $\theta_{\text {max }}(m, n)$, 日最低気温を $\theta_{\text {min }}(m, n)$ とすれば, 日平均気温 $\bar{\theta}(m, n)$ は,

$$
\bar{\theta}(m ; n)=\left(\theta_{\max }(m, n)+\theta_{\min }(m, n)\right) / 2
$$

で与えられる。したがって年平均気温 $\mathrm{t}_{\mathrm{m}}$ は，

$$
t_{m}=(1 / 364) \sum_{m} \sum_{n} \bar{\theta}(m, n)
$$

となる。また, 年振幅 $\mathrm{A}$ y は, 月平均気温の最大値 


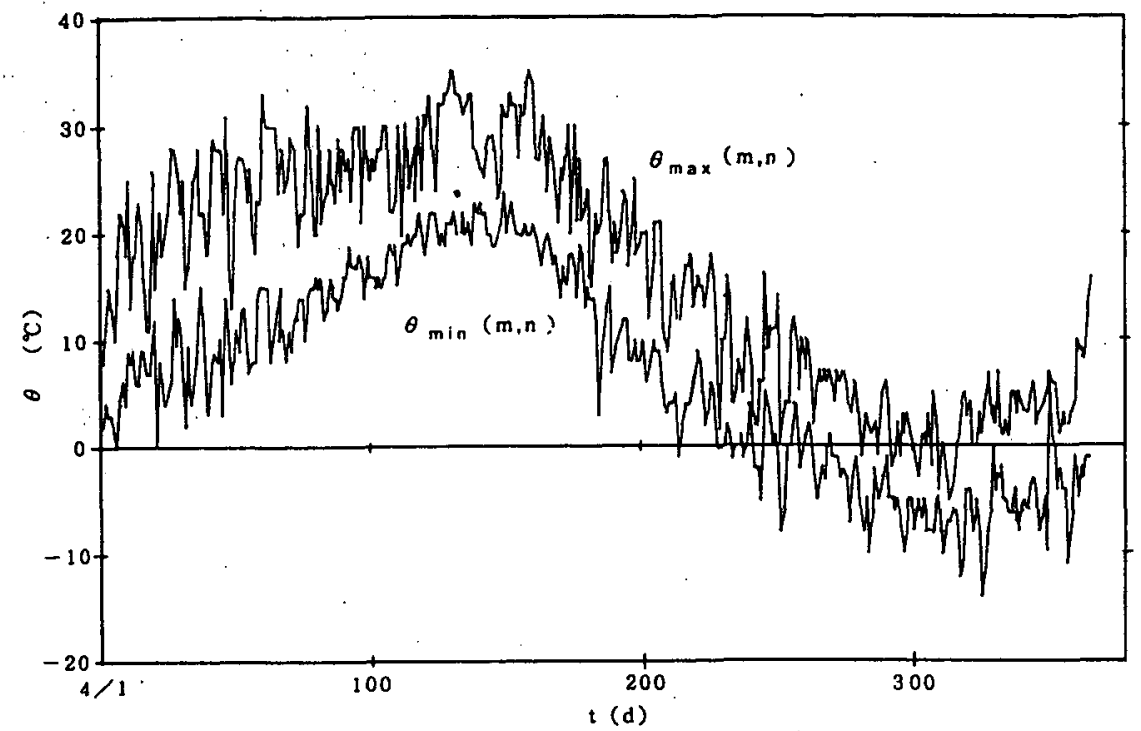

図-4 栄の内トンネルの日最高気温 $\theta_{\max }(m, n)$ と日最低気温 $\theta_{\operatorname{mim}}(m, n)$

$\overline{\boldsymbol{\theta}}_{\mathrm{m}=\max }$ とその最小値 $\overline{\boldsymbol{\theta}}_{\mathrm{m}-\max }$ 加ら, 近似的に,

$$
\begin{aligned}
& A_{y}=\left(\bar{\theta}_{\mathrm{m}=\max }-\bar{\theta}_{\mathrm{m}=\max }\right) / 2 \\
& \bar{\theta}_{\mathrm{m}=\max }=(1 / i) \sum_{\mathrm{n}} \theta(\max , n) \\
& \bar{\theta}_{\mathrm{m}=\min }=(1 / i) \sum_{\mathrm{n}} \theta(\min , n)
\end{aligned}
$$

で表すことができる。ここに $i$ は $m$ 月の日数であ る。

気温の日振幅 $A_{D}(m, n)$ は,

$$
A_{D}(m, n)=\left(\theta_{\max }(m, n)-\theta_{\min }(m, n)\right) / 2
$$

で表されるが，厳寒期の日振幅の月平均値 $\bar{A}_{D}$ は， $m=\min$ 月において,

$$
\bar{A}_{D}=(1 / 2 \mathrm{i}) \sum_{n}\left\{\theta_{\max }(\min , n)-\theta_{\min }(\min , n)\right\}
$$

となる。断熱つらら防止工の設計では, 日振幅 $A_{D}$ は厳寒期 $m=\min$ 月の月平均値 $\bar{A}_{D}$ を用いること ああるが，それにはかなり大きい標準偏差 $\sigma_{\mathrm{AD}}$ が 含まれるので, 設計には厳寒期 $m=m i n$ 月におけ

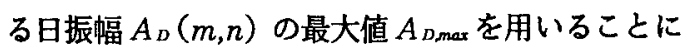
する。

また, 積算寒度 $F$ は負の日平均気温 $\bar{\theta}(m, n)<$ 0を合計したものであり，

$$
F=-\sum_{m} \sum_{n} \bar{\theta}(m, n)
$$

\section{として得られる。}

したがって実测データである $\theta_{\text {max }}(m, n)$ と $\theta_{\min }$ $(m, n)$ を用いれば，ある年度における变量 $\mathrm{X}_{i}$ すな わち，年平均気温 $t_{m} ，$ は式(11), その年振幅 $A_{Y}$ は 式(12), 日振幅 $\mathrm{A}_{\mathrm{D}}$ のうち月平均值 $\bar{A}_{D}$ は式(15)加 らまた月最大值 $A_{D, \text { max }}$ は式(14)に基づいて, 求め られることになる。これらの変量 $X_{i}$ を $m$ 年間につ いてまとめれは，Gumbel の第一種極值分布解析の ための基礎データが得られたことになる。

\section{2 トンネルの気像条件への適用例}

(1) 年平均気温, 年振幅と日振幅の極值分布解析 極値分布解析の一例として, 高山本線巣の内トン ネルの気象観測データをとりあげる。過去 7 年間の データについて，3.1にしたがって基礎データを算 出し, 年平均気温 $t_{m}$ については最小極值を, 年振

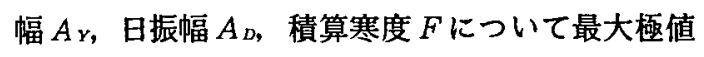
を式(8)によって極值分布解析した。なお $A_{D}$ に関 しては月平均值 $\bar{A}_{D}$, その標準编差 $\sigma_{\mathrm{AD}}$ と月最大値 $A_{D, \text { max }}$ について計算した。图ー5 $t_{m}$ と $A_{Y}$ の例 を示すが, 二重対数グラフの Gumbel の極値分布線 に乗っていることがわかる。

なお，宩の内トンネルの日振幅 $A_{D}$ の最大極値に ついて若干の解析を追加する。すなわち， $\bar{A}_{D}$, $\sigma_{A D}$ と $A_{D, \max }$ のそれぞれの確率密度 $\phi\left(2 \bar{A}_{D}\right), \phi$ $\left(2 \sigma_{\mathrm{AD}}\right), \phi\left(2 A_{D, \text { max }}\right)$ は図一6のようになるが, 


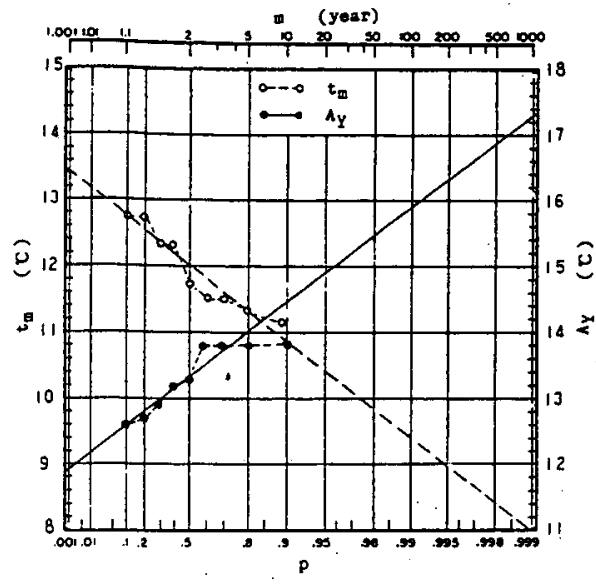

図ー5 巣の内トンネルにおける $t_{m}, A_{r}$ の 極值分布

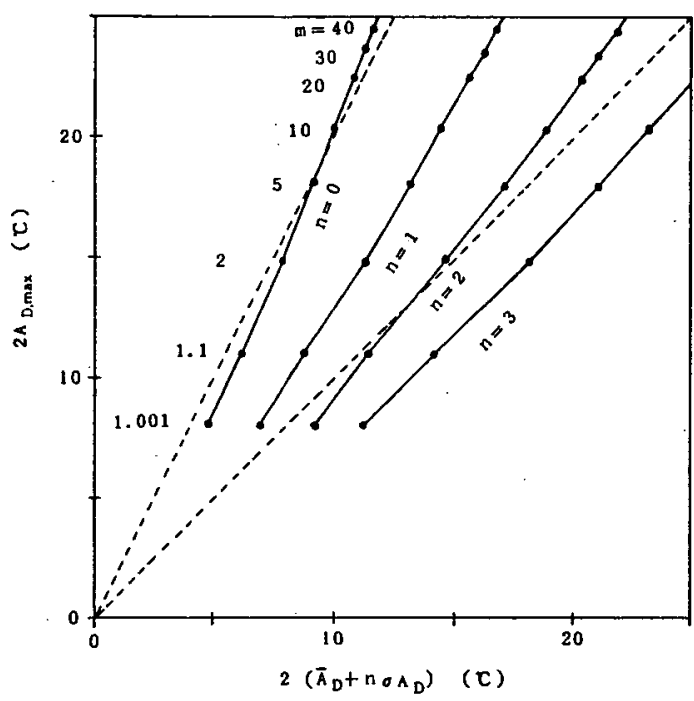

図一 $7 A_{D \max }$ と $\left(\bar{A}_{D}+\mathrm{n} \sigma_{A D}\right)$ の極值の比較

$A_{D, \max }$ と $\left(\overline{\mathrm{A}}_{\mathrm{D}}+n \sigma_{\mathrm{AD}}\right)$ との関係を $n$ をパラメー ターに描くと図ー7のようになる。このトンネルの 例によれば,

$$
A_{D, \max } \leftrightharpoons \bar{A}_{D}+2 \sigma_{\mathrm{AD}}
$$

で表される。

（2）年振幅, 日振幅之積算寒度の第一種極値分布の 適応性

年振幅 $A_{\gamma}$ ，日振幅 $A_{D}$ 之積算寒度 $F$ は非負の値 であるから，本来は第二種極値分布を用いるべきで あるが、ここでは第一種極値分布の最大極值, 最小

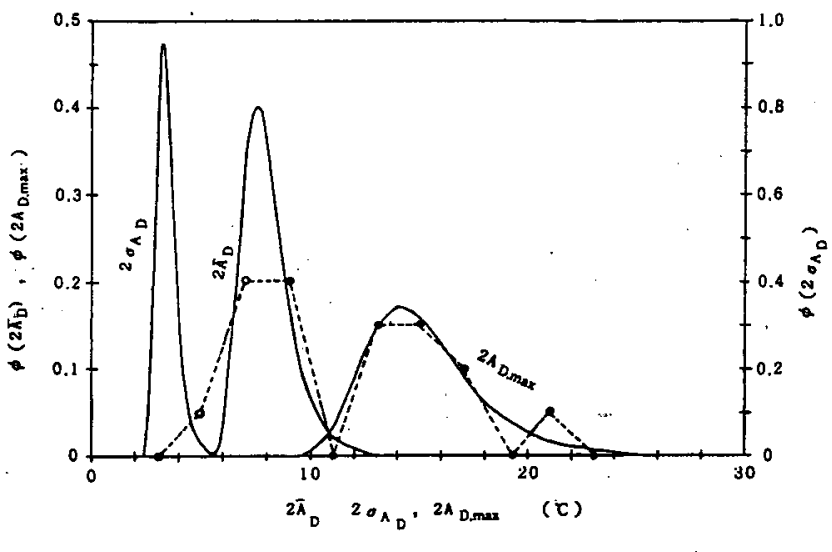

図一 6 日振幅に対する最大極值の確车密度 $\phi\left(2 \bar{A}_{D}\right)$, $\phi\left(2 \sigma_{A D}\right)$ ¿ $\phi\left(2 A_{D, \max }\right)$

極値の解析をしてきた。

この節では，第一種極値分布の啇応性について上 述の(1)のトンネルについて若干の検討を加える。負 の值を持たない第一種極値分布の最大極値に対する 日振幅 $\bar{A}_{D}, \sigma_{\mathrm{AD}}, A_{D, \max }$ の確率密度 $\phi\left(2 \bar{A}_{D}\right)$, $\phi\left(2 \sigma_{\mathrm{AD}}\right), \phi\left(2 A_{D, \max }\right)$ は図一6のようであ り,この例ではそれらの内最す小さい $\sigma_{\mathrm{AD}}$ ですら 2 . $5{ }^{\circ} \mathrm{C}$ 以上である。これらは, 最大極値を対象として いるので図ー6の右側の裾が本来問題となる。した がって, 確率密度 $\phi(y)$ が $y<0$ において十分小さ いから，近似的には y の非負の条件を満たすことに なり，第一種極值分布解析を用いても良いと考えら れる。

同様に積算寒度 $F$ あ非負の値を有するあのであ り，その最大極值の確率密度 $\phi(F)$ は図一8のよ うになる。困には巣の内トンネルだけでなく，名羽 線上羽幌トンネルと室蘭本線蘭法華トンネルにおけ る $\phi(F)$ の計算値も示した。積算寒度の小さい巣 の内トンネルでさえ， $F=0$ に対して $\phi(F)=1.7$ $\times 10^{-5}$ であり, 非負の条件を満足していると考え ても良さそうである。

したがって, 非負の値を有する日振幅 $\bar{A}_{D,} \sigma_{\mathrm{AD}}$ $A_{D, \text { max }}$ はもちろん, それらより絶対值の大きい年振

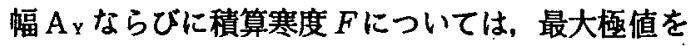
問題にする限りにおいては，第一種極値分布を用い てもよいと考えられる。 


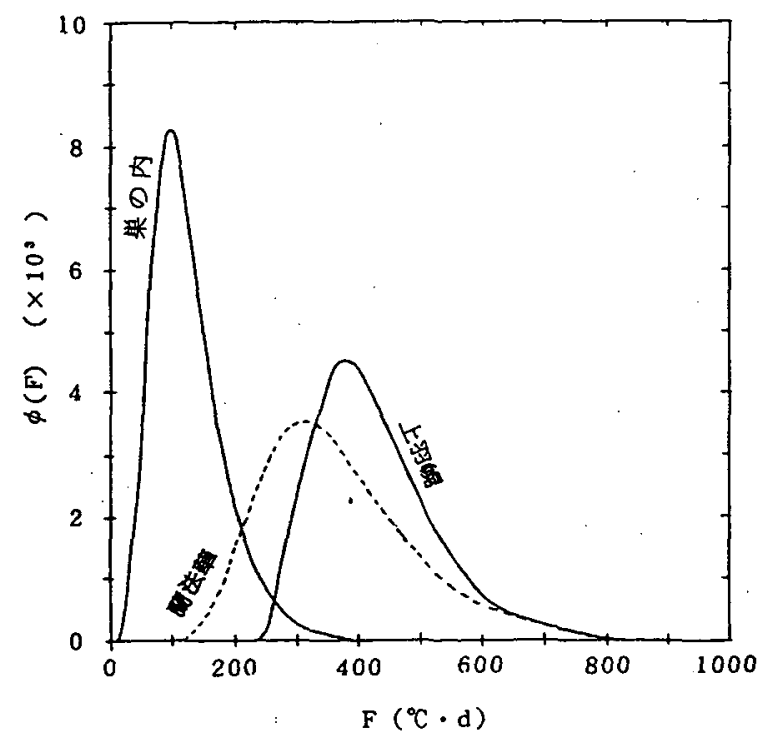

图一8 程雪寒度 $\boldsymbol{F}$ の最大㥛値の確率密度 $\phi(F)$

\section{4.トンネル外気温の気象条件の推定}

\section{1 年平均気温，年振幅と日振幅の最大值の}

それぞれの平均値と標準偏差の推定

トンネルの気象条件である年平均気温 $t_{\mathrm{m}}$ ，その 年振幅 $A y$, 日振幅 $A_{D}$ の最大極值あるいは最小極 値を求めるための基礎データとしては，トンネル近 傍の気象観測所によるすのが望ましいが，ここでは 代表的な気象官署のものを用いる。

寒冷地の代表的な気象官署 23 箇所, すなわち稚 内，北見枝幸，羽幌，雄武，留萌，旭川，網走，小 樽，札幌，岩見沢，帯広，釧路，根室，寿都，室蘭， 苫小牧, 浦河, 江差, 函館, 俱知安, 紋別, 広尾之 白棣をとりあげた。極值分布を求めるためのデー夕 数 $n$ は表一 1 のようであるが，札幌之帯広の $n=$ 91 年を筆頭に白棣の $n=19$ 年まで差がある。 $A_{D, \max }$ については 1965 年から 21 年間を対象とした。
表一1 寒冷地の代表的な都市に対す る年平均気温 $t_{m}$, 年振幅 $A y$ と日振愊の最大値 $\boldsymbol{A}_{\boldsymbol{D} \text {, max }}$ の データ数（年）

\begin{tabular}{|c|c|c|c|}
\hline & $t_{m}$ & $A_{Y}$ & $A_{D, \max }$ \\
\hline 内 & 42 & 42 & 21 \\
\hline 北見技幸 & 37 & 37 & 21 \\
\hline 羽 熀 & 35 & 35 & 21 \\
\hline 武 & 38 & 38 & 21 \\
\hline 㫜 & 37 & 37 & 21 \\
\hline III & 80 & 81 & 21 \\
\hline 走 & 89 & 90 & 21 \\
\hline 小 & 37 & 37 & 21 \\
\hline 札滉 & 91 & 91 & 21 \\
\hline 岩 見 沢 & 33 & 33 & 21 \\
\hline 広 & 64 & 64 & 21 \\
\hline 釧路 & 69 & 70 & 21 \\
\hline 室 & 91 & 91 & 21 \\
\hline 都 & 88 & 89 & 21 \\
\hline 室的 & 57 & 57 & 21 \\
\hline 苫小牧 & 38 & 38 & 21 \\
\hline 河 & 53 & 53 & 21 \\
\hline 美 & 38 & 39 & 21 \\
\hline 函 馆 & 38 & 39 & 21 \\
\hline 俱 知 㚣 & 36 & 36 & 21 \\
\hline 別 & 24 & 24 & 21 \\
\hline 尾 & 22 & 22 & 21 \\
\hline 榶 & 19 & 19 & 20 \\
\hline
\end{tabular}

表一 2 寒泠地の代表的な都市における年平均気温 $t_{m}$, 年振 愊 $A_{Y}$ 之日振愊の最大値 $A_{D, \text { max }}$ の平均値 $\mu \mathrm{r}$, 標準盾 差 $\sigma_{r}$ の一覧表

\begin{tabular}{|c|c|c|c|c|c|c|}
\hline & \multicolumn{2}{|c|}{$t_{m}\left({ }^{\circ} \mathrm{C}\right)$} & \multicolumn{2}{|c|}{$\overline{A_{Y}\left({ }^{\circ} \mathrm{C}\right)}$} & \multicolumn{2}{|c|}{$A_{D, \max }\left({ }^{\circ} \mathrm{C}\right)$} \\
\hline & $\mu_{\mathrm{Y}}$ & $\sigma_{\mathrm{Y}}$ & $\mu_{Y}$ & $\sigma_{Y}$ & $\mu_{\mathrm{Y}}$ & $\sigma_{Y}$ \\
\hline 内 & 6.28 & 0.55 & 12.88 & 1.00 & 5.37 & 1.12 \\
\hline 北見枝幸 & 5.53 & 0.58 & 13.36 & 1.08 & 6.86 & 1.04 \\
\hline 煶 & 7.11 & 0.50 & 13.26 & 0.83 & 8.22 & 1.14 \\
\hline 武 & 5.26 & 0.55 & 13.46 & 1.12 & 8.32 & 1.16 \\
\hline 留 & 7.24 & 0.49 & 13.24 & 0.80 & 7.37 & 0.88 \\
\hline 旭 & 5.84 & 0.69 & 15.44 & 1.15 & 8.68 & 1.06 \\
\hline 網 & 5.78 & 0.69 & 13.58 & 1.11 & 7.23 & 0.88 \\
\hline 小 & 8.24 & 0.51 & 13.00 & 0.90 & 6.27 & 1.59 \\
\hline 愢 & 7.42 & 0.71 & 13.73 & 0.93 & 6.87 & 1.12 \\
\hline 岩 見 沢 & 7.14 & 0.56 & 13.99 & 0.88 & 8.40 & 1.16 \\
\hline 枟 & 5.86 & 0.74 & 14.89 & 1.16 & 9.91 & 0.90 \\
\hline 路 & 5.49 & 0.82 & 12.58 & 1.03 & 9.22 & 1.04 \\
\hline 室 & 5.71 & 0.83 & 11.58 & 1.02 & 6.33 & 0.87 \\
\hline 陦 & 8.20 & 0.50 & 12.35 & 0.92 & 5.14 & 1.00 \\
\hline 两 & 8.32 & 0.60 & 12.06 & 0.81 & 4.27 & 0.80 \\
\hline 苫小牠 & 6.99 & 0.56 & 12.86 & 0.93 & 7.37 & 0.91 \\
\hline 间 & 7.49 & 0.70 & 11.95 & 0.88 & 5.35 & 0.70 \\
\hline 盖 & 9.46 & 0.52 & 12.25 & 0.79 & 5.31 & 0.81 \\
\hline 西 館 & 8.20 & 0.53 & 12.88 & 0.85 & 6.72 & 0.51 \\
\hline 俱 知 卉 & 6.24 & 0.53 & 13.85 & 0.92 & 10.41 & 1.25 \\
\hline 较 別 & 5.89 & 0.50 & 13.05 & 1.02 & 7.36 & 1.01 \\
\hline 広尾 & 6.54 & 0.51 & 12.08 & 0.69 & 7.99 & 0.83 \\
\hline 平均值 & 6.82 & 0.59 & 12.65 & 0.94 & 7.22 & 0.94 \\
\hline 標暲偏善 & 1.12 & 0.10 & 2.22 & 0.12 & 1.56 & 0.29 \\
\hline
\end{tabular}


年平均気温 $t_{m}$ は式(11)加ら求めるが,つらら防 止工を対象としているので 4 月から翌 3 月までにつ いて整理した。同様に，年振幅 $A r$ 年度を対象と し. 月平均値の最大値 $\bar{\theta}_{m=\text { max }}$ と最小値 $\bar{\theta}_{m=\min }$ から 式(12)によって求めた。さらに日振幅の最大値 $A_{D, \max }$ は, 各年度における 2 月の日最高気温 $\theta_{\text {max }}$ $(2, n)$ 上日最低気温 $\theta_{\text {min }}(2, n)$ に基づく式(14)の $A_{D}(2, n)$ の $\mathrm{n}$ 日間の最大值として定義した。

表一 1 に示す $n$ 年間の統計データについて, 年平 均気温 $t_{m}$, 年振幅 $A_{Y}$ と日振幅の最大值 $A_{D_{\text {max }}}$ のそ れぞれの平均値 $\mu_{\mathrm{Y}}$ と標準偏差 $\sigma_{\mathrm{Y}}$ を求めると表一 2のようになる。

これら 23 都市の $\mu_{\mathrm{y}}$ と $\sigma_{\mathrm{Y}}$ の平均值と標準扁差は, $t_{m}$ についてはそれぞれ $\mu_{\mathrm{Y}}=6.8^{\circ} \mathrm{C}$ $\sigma_{\mathrm{Y}}=0.6^{\circ} \mathrm{C}$ て あり, $A_{\mathrm{Y}}$ については $\mu_{\mathrm{Y}}=12.7^{\circ} \mathrm{C}$ 的 $=0.9^{\circ} \mathrm{C}$,

\section{表一 3 寒冷地の代表的な都市における年平均気温} $t_{\text {m }}$ 年振愊 $A$, と日振愊の最大值 $A_{\text {p } \text { max }}$ に 対する極值算定式の定数 $u$

\begin{tabular}{|c|c|c|c|}
\hline & \multicolumn{3}{|c|}{ u } \\
\hline & $t_{m}$ & $A_{Y}$ & $A_{D, m a x}$ \\
\hline 内 & 6.541 & 12.402 & 4.826 \\
\hline 北見枝幸 & 5.806 & 12.841 & 6.346 \\
\hline 螳 & 7.351 & 12.864 & 7.657 \\
\hline 武 & 5.522 & 12.926 & 7.747 \\
\hline 明 & 7.475 & 12.858 & 6.941 \\
\hline 川 & 6.161 & 14.908 & 8.163 \\
\hline 走 & 6.102 & 13.064 & 6.795 \\
\hline 小 & 8.488 & 12.570 & 5.492 \\
\hline 䖧 & 7.418 & 13.300 & 6.318 \\
\hline 岩 見 讯 & 7.409 & 13.570 & 7.829 \\
\hline 広 & 6.210 & 14.345 & 9.467 \\
\hline 路 & 5.870 & 12.102 & 8.712 \\
\hline 室 & 6.100 & 11.105 & 5.906 \\
\hline 都 & 8.439 & 11.929 & 4.652 \\
\hline 硐 & 8.605 & 11.688 & 3.881 \\
\hline 苫小牧 & 7.258 & 12.412 & 6.924 \\
\hline 河 & 7.819 & 11.534 & 5.011 \\
\hline 差 & 9.706 & 11.880 & 4.916 \\
\hline 館 & 8.452 & 12.474 & 6.459 \\
\hline 俱知安 & 6.487 & 13.406 & 9.797 \\
\hline 別 & 6.140 & 12.554 & 6.861 \\
\hline 尾 & 6.796 & 11.745 & 7.585 \\
\hline 均 & 6.449 & 12.658 & 6.740 \\
\hline 標軼徧差 & 2.168 & 0.883 & 1.533 \\
\hline
\end{tabular}

$A_{D_{\max }}$ については $\mu_{\mathrm{Y}}=7.2^{\circ} \mathrm{C}$ と $\sigma_{\mathrm{Y}}=0.9^{\circ} \mathrm{C}$ あ゙る ので, 23 都市の平均的な年平均気温は $t_{m}=6.8^{\circ} \mathrm{C}$, 年振幅は $A_{Y}=12.7^{\circ} \mathrm{C}$, 日振幅の最大值は $A_{D_{\text {m max }}}=$ $7.2^{\circ} \mathrm{C}$ 言える。

極值分布解析には統計デー夕の個数 $n$ に体存する $y_{n}$ と $a_{n}$ が必要となるが，表一 1 の $n$ に対して式 (9)より $u$ と $а$ を求めれば表一 3 と表一 4 のように なる。

\section{2 年平均気温の最小绿值分布推定}

年平均気温 $t_{m}$ は式(8)の最小極值 $y_{p}$ として与え られるが，各都市の再現期間 $m$ に対する極値の出 現倾向をみるために，図一9のように，最小極值分 布を重㭘わせた。この時, デー夕数 $n$ の再現期間

表ー4 寒冷地の代表的な都市における年平均気温 $t_{m,}$ 年振福 $A_{r}$ と日振愒の最大值 $A_{p, \text { max }}$ に 対する極值算定式の係数 $\alpha$

\begin{tabular}{|c|c|c|c|}
\hline & \multicolumn{3}{|c|}{$\alpha$} \\
\hline & $t_{m}$ & $A_{Y}$ & $A_{D \text {.max }}$ \\
\hline 内 & 2.068 & 1.142 & 0.956 \\
\hline 北見技幸 & 1.963 & 1.043 & 1.023 \\
\hline 愰 & 2.250 & 1.361 & 0.932 \\
\hline 武 & 2.049 & 1.006 & 0.918 \\
\hline 朗 & 2.295 & 1.403 & 1.221 \\
\hline III & 1.725 & 1.036 & 1.011 \\
\hline 走 & 1.723 & 1.079 & 1.220 \\
\hline 梅 & 2.224 & 1.250 & 0.674 \\
\hline 榥 & 1.684 & 1.295 & 0.954 \\
\hline 岩 見 沢 & 2.017 & 1.279 & 0.925 \\
\hline 広 & 1.589 & 1.009 & 1.182 \\
\hline 路 & 1.443 & 1.149 & 1.027 \\
\hline 室 & 1.441 & 1.020 & 1.222 \\
\hline 都 & 2.400 & 1.307 & 1.066 \\
\hline 室而 & 1.938 & 1.452 & 1.329 \\
\hline 苫小牧 & 2.042 & 1.216 & 1.175 \\
\hline 河 & 1.675 & 1.323 & 1.530 \\
\hline 军 & 2.198 & 1.436 & 1.319 \\
\hline 馆 & 2.156 & 1.333 & 2.085 \\
\hline 俱知安 & 2.148 & 1.229 & 0.854 \\
\hline 別 & 2.141 & 1.064 & 1.054 \\
\hline 尾 & 2.069 & 1.556 & 1.294 \\
\hline 均 & 1.965 & 1.227 & 1.135 \\
\hline 摽隼偏差 & 0.270 & 0.159 & 0.280 \\
\hline 1 , 平均 & 0.519 & 0.832 & 0.897 \\
\hline 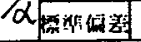 & 0.079 & 0.106 & 0.278 \\
\hline
\end{tabular}




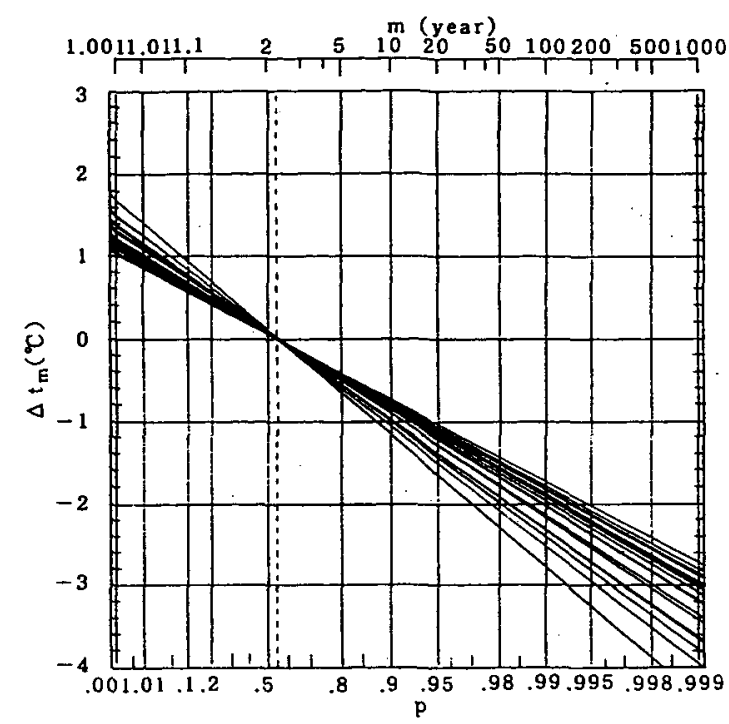

図-9 寒冷地における年平均気温の増分 $\Delta t_{\text {。 }}$ と 再現期間 $m$ の関係

$m$ に対する奇与は非常に小さいので $n \rightarrow \infty$ として, $m=2.339$ 年を基準とした。これは極值 $y_{p}$ がデー 夕の平均値 $\mu \mathrm{Y}$ に等しくなるときの再現期間である。

これらの直線群の勾配は表ー4の1/ 23 都市の平均値と標準偏差はそれぞれ 0.519 之 0.079 であり, 直線群はかなり収束している。その 平均的な勾配を考えれば，再覞期間 $m=2.34$ 年を $\Delta t_{m}=0^{\circ} \mathrm{C}$ とする式は，

$$
\Delta t_{m}=0.303+0.519 \ln \left(-\ln \left(1-m^{-1}\right)\right)
$$

で表される。これはデータの平均値が $\mu_{\mathrm{y}}=0$ とな る時の最小極值分布を示すすのであるから，ある トンネルの平均的な年平均気温 $\bar{t}_{m}$ が判っていると きには，再現期間 $m$ 年に対する年平均気温 $t_{m}(m)$ は,

$$
t_{m}(m)=\bar{t}_{m}+0.303+0.519 \ln \left(-\ln \left(1-m^{-1}\right)\right)
$$

\section{によって近似できる。}

\section{3 年振幅の最大極値分布推定}

年振幅 $A_{Y}$ の最大極值分布も $t_{m}$ 之同様にして表一 3 と 4 の と $а$ を式(8)に代入することによって求 めることができる。年振幅の増分 $\Delta A Y$ について, 再現期間 $m=2.34$ 年を原点として重ね合わせたの が図ー10である。この直線群の勾配 1 / $a$ の平均値

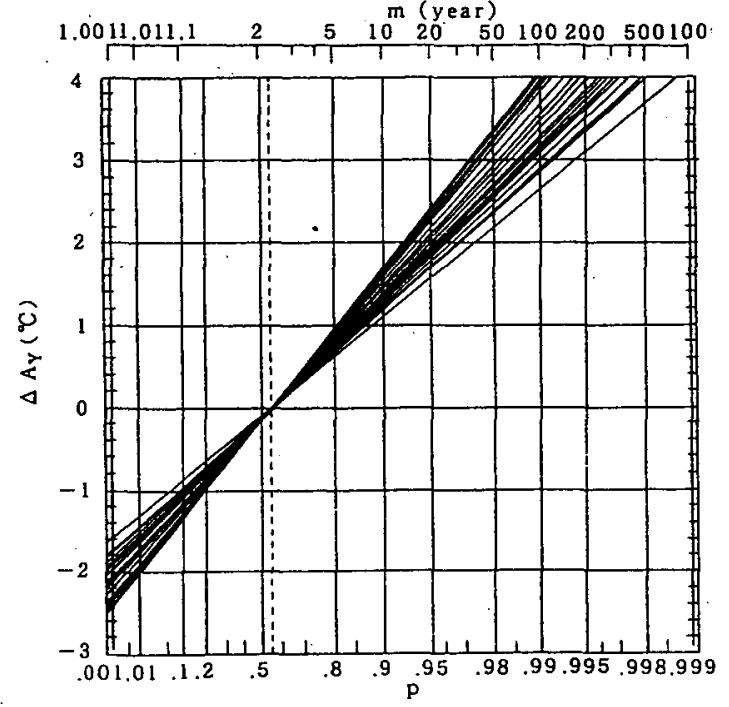

困一-10 寒冷地における気温の年振愊の增分 $\Delta A r$ と再現期間 $m$ との関保

と標準偏差はそれぞれ 0.832 と 0.106 である。この 直線群も比較的良く収束しており，平均的には

$$
\Delta A_{Y}=-0.485-0.832 \ln \left(-\ln \left(1-m^{-1}\right)\right)
$$

で表される。あるトンネルの平均的な年振幅は $\bar{A} \mathbf{Y}$ しか与えられていないときには，再現期間 $m$ 年に 対する $A_{Y}(m)$ は,

$$
A_{Y}(m)=\bar{A}_{r}-0.485-0.832 \ln \left(-\ln \left(1-m^{-1}\right)\right)
$$

で推定できる。

\section{4 日振幅の最大值の最大極値分布推定}

日振幅の最大値 $A_{D, \text { max }}$ の最大極值分布む $A_{Y}$ 之同 様にして求めることができる。日振幅の最大値の増 分 $\Delta A_{D, \max }$ について整理すると図一11のようになる が，図ー9や10に比べばらつきが大きい。大きな ばらつきを示すのは小樽と函館, 浦河である。前者 は勾配が急で，後 2 者は緩やかである。

図一11 は平均値 $\mu_{\mathrm{Y}}$ に対する増分 $\Delta A_{n, \text { max }}$ を示す あのであるが， $A_{D, \max }$ の絶対値を描くと図一12のよ うになる。 $m=2.34$ 年の時でも， $4<A_{D, \text { max }}<10$ ${ }^{\circ} \mathrm{C}$ 範囲にわたり, 緯度の低い海岸部では低く, 内 陸部では高くなる。

このように $A_{\text {D. max }}$ ではその増分です絶対値です 


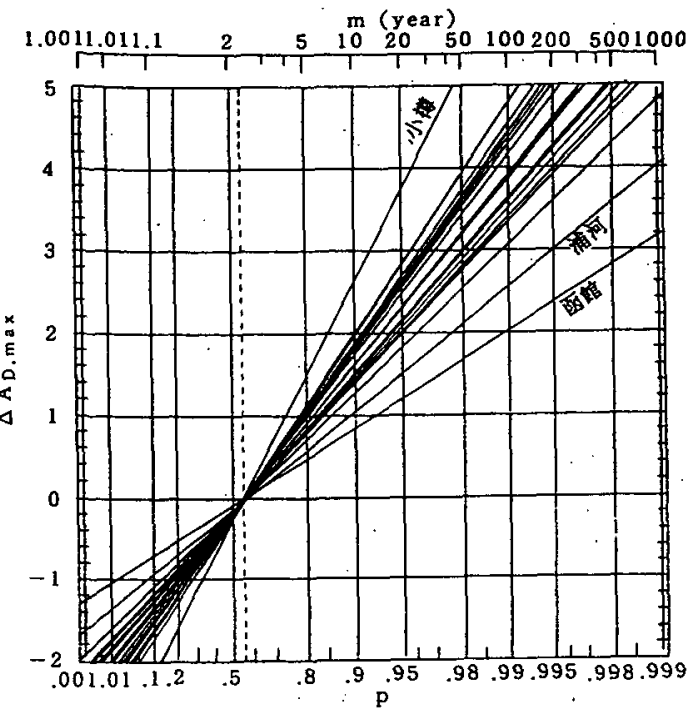

图一11寒冷地における気温の日振嘼の最大値の 增分 $\Delta A_{v_{\max }}$ と再現期間 $m$ との関係

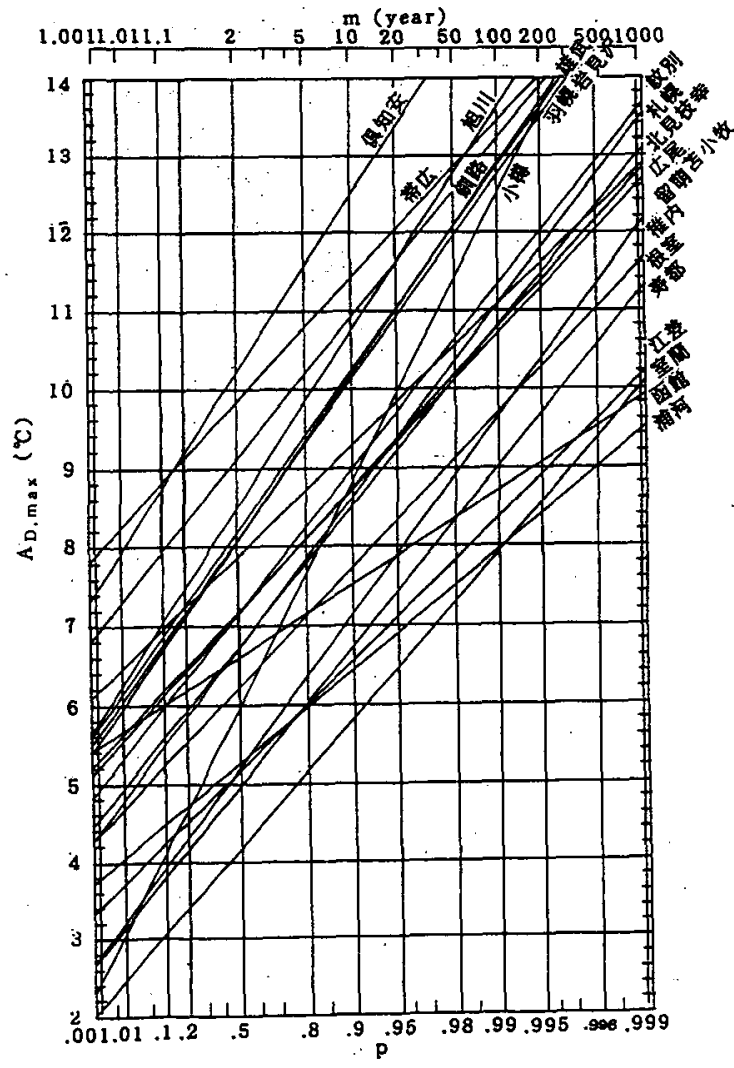

図ー12 寒冷地における各都市の気温の日振愊の 最大値 $A_{D_{\max }}$ と再現期間 $m$ との関係
かなりのばらつきを示すが，平均的な最大極值分布 としては,

$$
\Delta A_{D \max }=-0.523-0.897 \ln \left(-\ln \left(1-m^{-1}\right)\right)
$$

で表される。あるトンネルの平均的な日振幅の最大 值 $\bar{A}_{D, \text { max }}$ が判っているときは, 再現期間 $m$ 年に対 Lて,

$A_{D, \max }(m)=\bar{A}_{D_{, \max }}-0.5-0.9 \ln \left(-\ln \left(1-m^{-1}\right)\right)$

で推定できる。

\section{5 気象条件の統計量の算定}

トンネルの断熱つらら防止工の設計において必要 となる気象条件については，上述の 4.1 4.4 に示 した手法により，年平均気温 $t_{m}$ については最小極 值分布解析により, 年振幅 $A \mathrm{r}$ と日振幅の最大檤

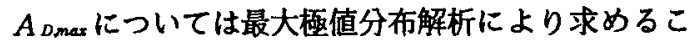
とが可能である。しかし，過去の時系列データがな く, 平均値 $\bar{t}_{m}, \bar{A}_{r}, \bar{A}_{D, \max }$ しか判らないときがあ る。この場合には $t_{m}$ と $A_{Y}$ については式(19)と式 （21)により精度良く，A $A_{\text {max }}$ については若干のばら

表一 5 再現期間 $m$ に対する增分 $\Delta t_{\mathrm{m}}, \Delta A_{Y}$ と $\Delta A_{D_{\max }}$

\begin{tabular}{|r|r|r|r|r|}
\hline $\begin{array}{r}|c| \\
\mathrm{m}\end{array}$ & $\begin{array}{c}\Delta \mathrm{t}_{\mathrm{m}} \\
\left({ }^{\circ} \mathrm{C}\right)\end{array}$ & $\begin{array}{c}\Delta \mathrm{A}_{\mathrm{Y}} \\
\left({ }^{\circ} \mathrm{C}\right)\end{array}$ & $\begin{array}{c}\Delta \mathrm{A}_{\mathrm{D}, \max } \\
\left({ }^{\circ} \mathrm{C}\right)\end{array}$ & $\begin{array}{c}\mathrm{A}_{\mathrm{D}, \max } \\
\left.{ }^{\circ} \mathrm{C}\right)\end{array}$ \\
\hline 2 & 0.112 & -0.181 & -0.194 & 7.0 \\
\hline 3 & -0.166 & 0.266 & 0.287 & 7.5 \\
\hline 5 & -0.475 & 0.763 & 0.822 & 8.0 \\
\hline 10 & -0.865 & 1.387 & 1.495 & 8.7 \\
\hline 20 & -1.239 & 1.986 & 2.141 & 9.3 \\
\hline 30 & -1.453 & 2.331 & 2.513 & 9.7 \\
\hline 40 & -1.605 & 2.574 & 2.775 & 10.0 \\
\hline 50 & -1.722 & 2.761 & 2.977 & 10.2 \\
\hline 60 & -1.818 & 2.915 & 3.142 & 10.4 \\
\hline 70 & -1.898 & 3.043 & 3.281 & 10.5 \\
\hline 100 & -2.084 & 3.342 & 3.603 & 10.8 \\
\hline 150 & -2.296 & 3.681 & 3.968 & 11.2 \\
\hline
\end{tabular}


つきを有するが式(23)により，推定が可能となった。

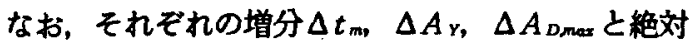
值 $A$ D再再現期間 $\mathrm{m}$ についてまとめると表一 5 のようになる。

・したがって，あるトンネルに対する気象条件の再 現期間 $\mathrm{m}$ を与えれば，つらら防止工の防炎強度 (設計頋用期間) に応じた $t_{m}, A_{y}, A_{\mathrm{D}}$ が求められ ることになり，式(1)に示す $t_{m} / A_{r}$ と $\eta$ が得られ， 断熱つらら防止工の断熱材の厚さや幅を合理的に決 定できることになる。

\section{5.あとがき}

トンネルの倲害・つらら防止工の一つである断熱 工法は，既設トンネルでは表面断熱工法として，新 設トンネルでは断熱二重巻覆工工法として，多くの 施工実績を皘み重わ，メンテナンスフリートンネル として保守サイドからだけでなく建設サイドからす 着目されている。

当論文は，断熱つらら防止工法の設計の基本とな る気象条件を Gumbel の第一種極值分布解析を用い て推定する手法について述べたものである。断熱つ らら防止工の設計を進めるためにはトンネルの気象 条件を入力する必要があるが，多くの場合それを的 確に求めることは困難であることが多い。この気象 条件を確率量として求め, それにしたがってつらら 防止工を設計すれば，つらら防止工の防災強度が定
量的に確定できることになる。当論文はこのような 背景にもとついて, トンネルの防災強度あるいは設 計耐用年数が与えられれば，必要となるトンネル外 気温の年平均気温, その年振幅と日振幅が容易に推 定できる手法を提案したものでありこれによって 断熱つらら防止工の設計断熱材厚さやその幅を合理 的算定でることになった。

\section{弆考文献}

1) 岡田, 松本 : 既設トンネルにおける気象条件の 確率量を考慮した断熱つらら防止工の断熱材の最 適化，土木学会論文集，No.400, 1988

2 ) 岡田, 松本 : 断熱二重巻覆工におけるトンネル のつらら防止工法の断熱材の最適化に関する研究, 土木学会論文集, No.388, 1987

3 ) 岡田, 松本 : 寒冷地トンネルにおけるつらら発 生領域に関する統計的理論的解析, 土木学会論文 集, No.388, 1987

4) 岡田, 松本: 断熱つらら防止工を施工したトン ネルにおけるトンネル内気温の減衰乙断熱材厚さ に関する簡易推定法，土木学会論文集，No.439， 1991

5) Gumbel : Statistics of extreme, Columbia university press, P.201/305, 1958

6 ) Gumbel : Statistical theory of dought, Proc. of ASCE, Vol.80, No.439 


\section{SYNOPSIS}

\section{Estimation of Atmospheric Condition for Designing of Frost Damage and Frost Heave Prevention in Tunnel}

\section{By Katsuya OKADA}

General manager of Civil Engineering Division, Maglev System Development Depertment, Railway Technical Reserch Institute, Dr. Eng.

In cold climate tunnels, icicles and sidewall ices grow at the lining surface, and frost heaves of rocks occur at the back of the lining. For a purpose of these frost damage and frost heave of the tunnel, an adiabatic icicle prevention work has been provided in many railway tunnels.

To design the icicle prevention work, it is desirable to estimate reasonably atmospheric condition at the outside of tunnel.

This paper deals with a statistical estimation method of the atmospheric condition such as yearly mean air temperature, yearly amplitude and daily amplitude, which are based on an exreme distribution analysis. 